\title{
THE ENERGY DEMAND OF AGRITOURISM FARMS IN POLAND
}

\author{
Michal Roman ${ }^{1}$, Kamil Roman ${ }^{2}$ \\ ${ }^{1}$ Warsaw University of Life Sciences in Warsaw, Poland; \\ ${ }^{2}$ Institute of Technology and Life Sciences in Warsaw
}

\begin{abstract}
The purpose of the article was to present the importance of agritourism as a non-agricultural business activity in rural areas. Particular attention has been paid to elements of agritourism innovation, as a basic form of recreation in rural areas. The innovation development can be based on natural resources, cultural heritage of the area and the involvement of institutions and the local community. The sustainable economic development as a part of innovativeness development leads to improvement of the living standard of the rural community. The example of the innovation is usage of heat pumps, which could be placed in rural buildings. Transformation of the energy stored in the ground into thermal energy is the purpose of described devices. The annual total operating costs of space heating in the agritourism farm were also calculated in presented article. Based on the collected data the formula for the energy needs in agritourism facilities was presented. The value of energy demand of agritourism farms in Poland in the years 1998-2015 amounted to 5035816.8 TJ.
\end{abstract}

Key words: rural tourism, agritourism, rural areas, innovations, heat pumps, Poland.

JEL code: Q12, Q13, Q40, Q42, Q43, Q47

\section{Introduction}

Agritourism is the basic form of recreation in rural areas, using its own accommodation base on the farm, along with the possibilities of feeding tourists and implementation of agricultural program, cultural and recreational education in the natural environment (Roman M., Niedziolka A., 2017). The development is based on natural resources, cultural heritage of the area and the involvement of institutions and the local community (Gospodarek J., 2001). Because the air pollution in cities is still increasing, there is also growing interest of health awareness and the desire to use the values of rural life such as fresh air, the possibility of active rest, stress-free situations, safety and friendly attitude of rural residents to tourists (Ollenburg C., Buckley R., 2007). Currently, the tourists are looking for seclusion and relaxation on nature areas, enforcing to spend the vacations with the possibility of countryside short rest (Sikora J., 1999).

The attractiveness of agritourism come from the advantages of rural areas (the value of internal and external agricultural and forest areas environment) such as clean air and water, natural wealth of the vegetable and animal world, monuments of rural architecture, local and regional cuisine, folk culture, history, hospitality of local hosts and other residents of the village, peaceful and security.

However, the great importance lies in the innovative ways of agritourism development, which considers the modernity and competitiveness growth (Wielewska I., 2017). It also requires support with knowledge that can be provided by professional advisory services (Prus P., Drzazdzynska K., 2017). These are an indispensable element of agritourism economy increase. In many cases, the new form of applied solutions can improve the work in rural buildings, using the renewable energy sources such as heat pumps.

\section{Material and the research method}

The purpose of the article was to present the importance of agritourism as a non-agricultural business activity in rural areas. Particular attention has been paid to elements of agritourism innovation, presenting the heat pumps usage in the agritourism facilities. Applied innovation should be profitable, that is why the total annual financial burden was calculated. The study contains the review based on literature documents and authors' own experience. The proposed calculation of 
total annual financial burden connect with energy consumption costs (ECC), capital costs (CC) and depreciation costs (DC).

\section{Agritourism as a factor of rural development}

Agritourism activity should be considered from the supply and demand side (Golebiewska B., 2015). The supply side is represented by the "interests" of active farms, providing services based on a tourist product and its competitiveness (Philip S., Hunter C., Blackstock K., 2010). Second side concerns tourists, which reports the demand and level of the satisfaction according to the offered tourism product and its attractiveness (Roman M., Roman M., Roman K., 2018). Agritourism consists of two parts: agro (Greek agros - role, agronomos - referring to the agricultural property management) and tourism (a form of active rest away from the place of residence and employment, which is inspired by cognitive, recreational, healing and cognitive needs, sports, entertainment, commitments to family, friends and institutions, including religious) (Sznajder M., Przezborska L., 2006). In the implementation of recreational, cognitive, health, sentimental or family purposes, advantages of local cultural heritage and natural diversity are used (Roman M., Roman M., 2014). The basic functions can be specified (Knecht D., 2009; Roman M., Niedziolka A., 2017):

- profitable (additional source of income as non-agricultural activities);

- cognitive (learning about life, culture, professions of the local community);

- activation of rural areas;

- educational, including ecological (maintaining cleanliness and nature learning);

- conservation of natural and cultural resources;

- sport recreation (active recreation, improvement of health condition).

Over the years, the agritourism in Poland developed dynamically. Detailed data are presented in Figure 1.

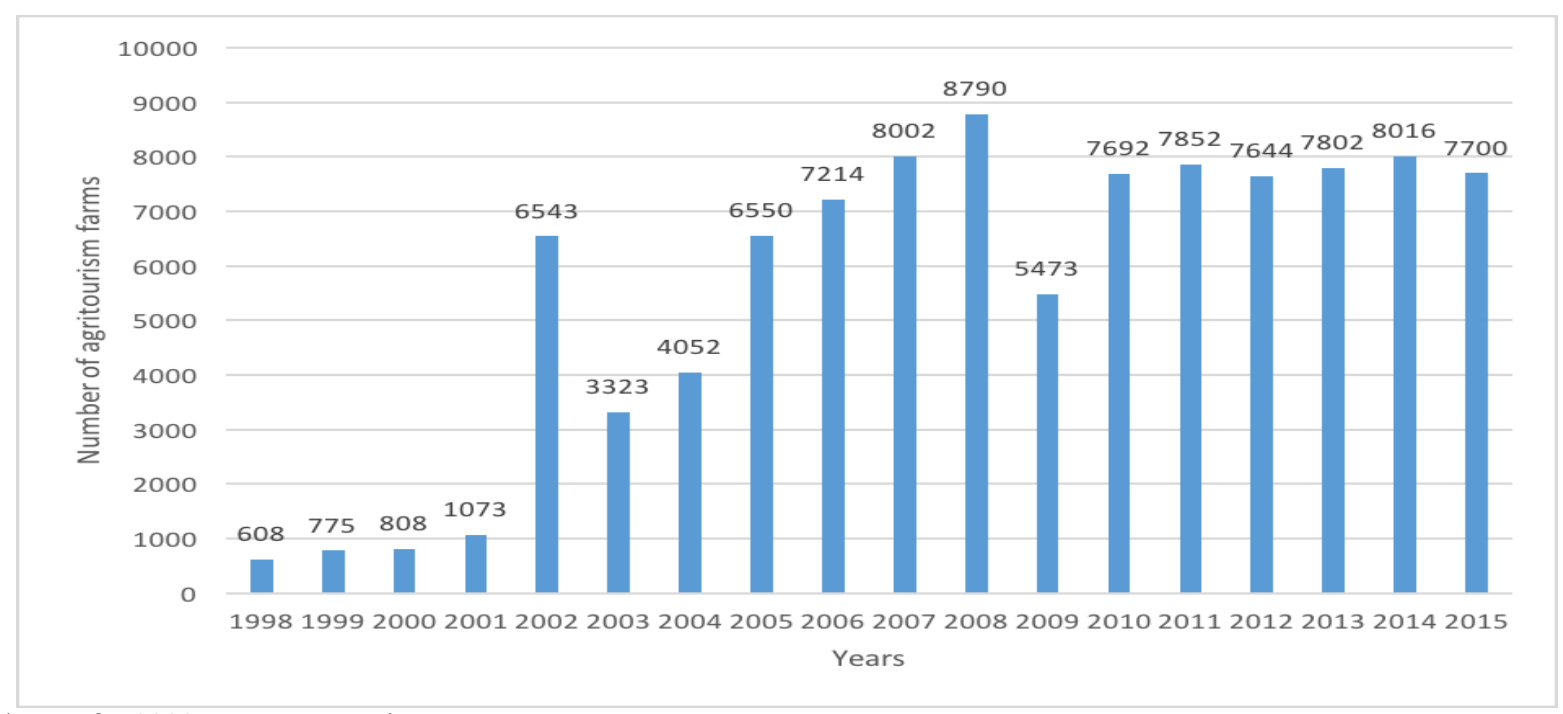

* Data for 2008 were estimated.

Source: authors' study based on the data of the Central Statistical Office "Tourism", series: "Information and Statistical Studies" from 1998, 1999, 2000, 2001, 2009, 2010, 2011, 2012, 2013, 2014, 2015, data of the Institute of Tourism from 2002, 2003, 2004, 2005, 2006, 2007, data obtained from agricultural advisory centres in Poland.

\section{Fig. 1. Number of agritourism farms in Poland in 1998-2015}

Information about numbers of agritourism farms each year was collected by various institutions, like Ministry of Agriculture and Rural Development, Institute of Tourism or Central Statistical Office. The dynamic increase in the number of agritourism farms to nearly 8.000 facilities in 2015 can be noticed. Location of agritourism farms in Poland was presented in Figure 2. 
Source: Bednarek-Szczepanska M., Banski J., 2014

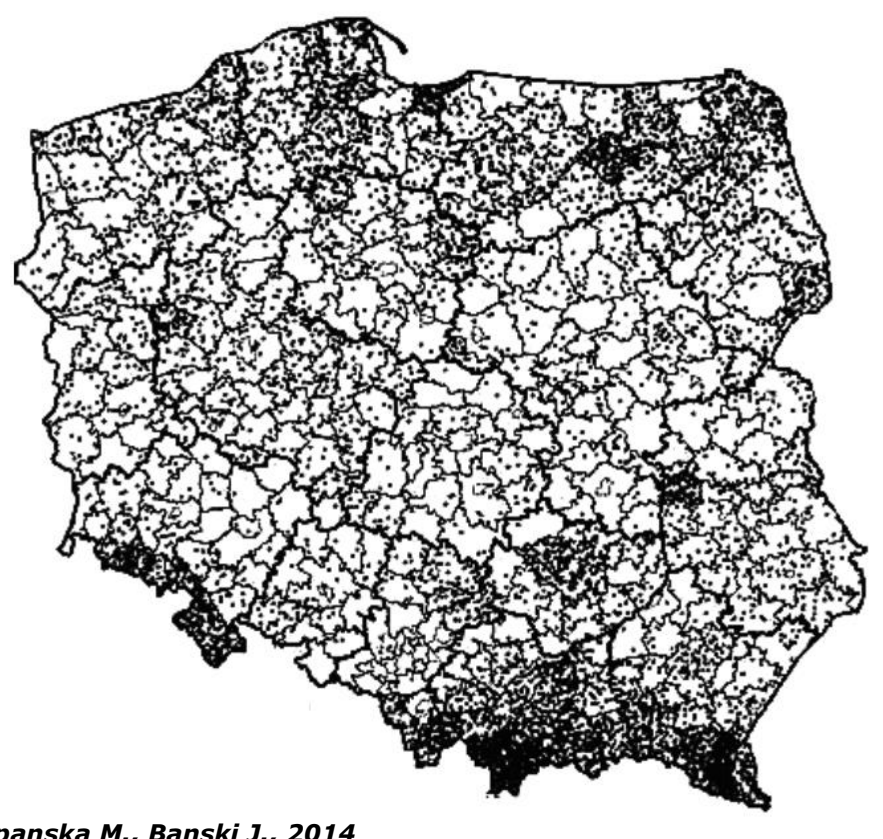

Fig. 2. Distribution of agritourism farms in Poland

Most agritourism farms are located on natural-valuable areas with good environmental conditions (i.e. mountains, sea, Masuria). Most of objects are located in the eastern part of Poland in Podlasie, Lubelskie and Podkarpackie voivodeship.

The example of the innovation is usage of heat pumps, which could be placed in rural buildings. Transformation of the energy stored in the ground into thermal energy. The heating system is very effective and ecological during the hot water preparation (http://www.gospodarzzenergia.pl/gruntowe-pompy-tupla, access 26/11/2017). Integrated system can operate nonstop, acquiring accumulated energy stored in soil, subsurface waters, atmosphere and geothermal energy. The studied energy sources are characterized as lower heat sources (http://www.nowoczesnegrzanie.pl/pompy-ciepla.html, access 26/11/2017). Heat pumps are supplied with electricity, most frequently through compressor supply.

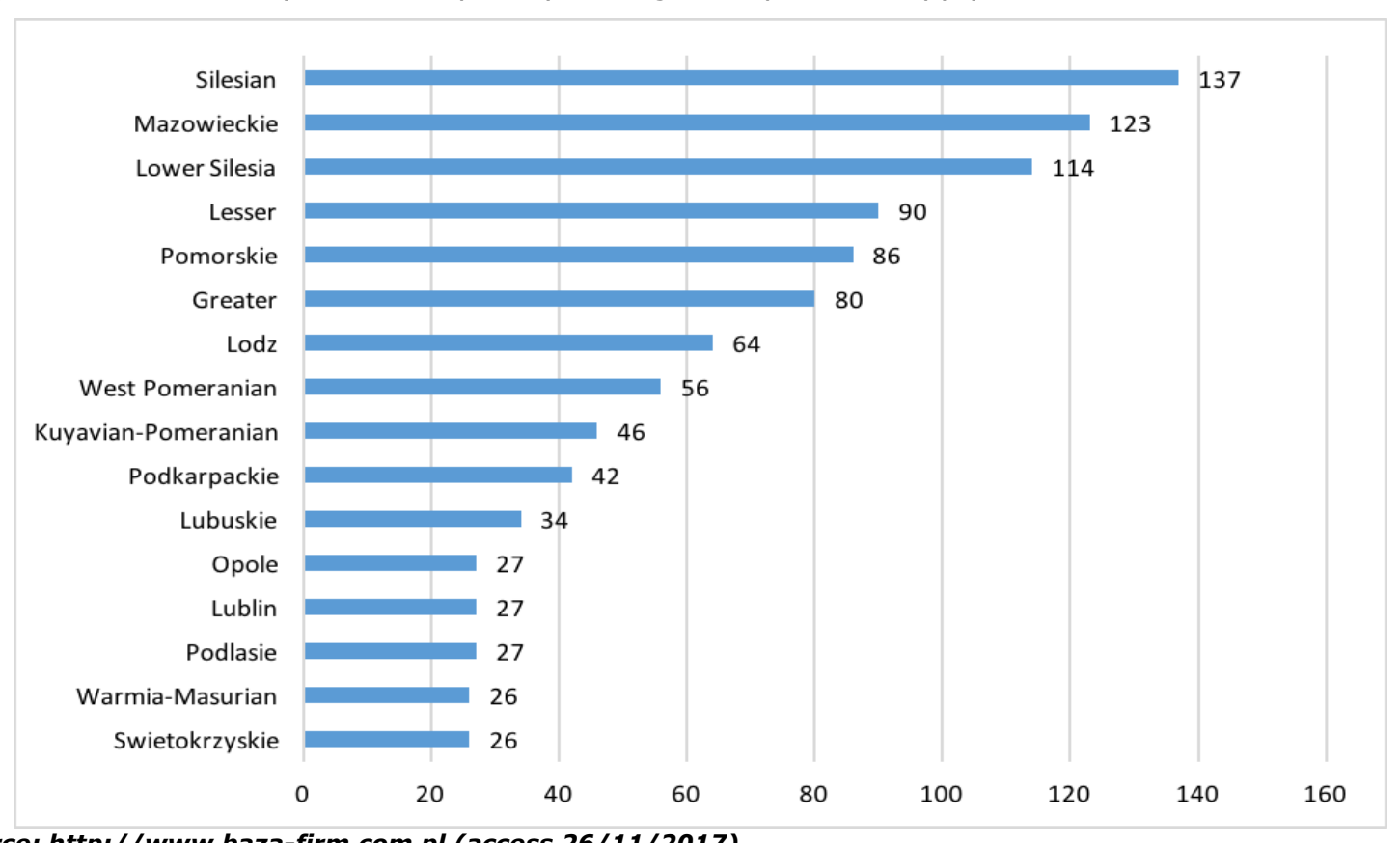

Source: http://www.baza-firm.com.pl (access 26/11/2017)

Fig. 3. The number of registered companies in individual voivodships of Poland 
Market analysis according to Business Navigator (BN) website was made. BN website contains the data of 1005 verified companies that produce the heat pumps. The number of registered companies in individual voivodships is presented in Figure 3.

Operating costs and capital expenditures of heat pumps usage can be determined by comparing their total installation cost in agritourism buildings. The average area of building should have $200 \mathrm{~m}^{2}$ and should use at least in $15 \%$ of renewable energy from the heat pumps work. It was assumed that the standard heat power is about $70 \mathrm{kWh} / \mathrm{m}^{2}$ per year. The two variants of applied heat pumps were compared during performed calculations. The SPF efficiency factor of air-to-water heat pump was equal 3.3; for the brine-water type SPF factor reached 4.3. The ground heat exchanger was applied on the $350 \mathrm{~m}^{2}$ of surface. The list of costs of investment elements for the considered case is presented in Table 1.

Table 1

List of costs of investment elements for the case under consideration (PLN)

\begin{tabular}{|l|c|c|c|}
\hline \multicolumn{1}{|c|}{ Type of investment element } & Standard period of use, years & Example I & Example II \\
\hline Heat pumps & 20 & 26000 & 27000 \\
\hline Lower source & 50 & 2000 & 12000 \\
\hline Electrical installation with control & 20 & 3000 & 3000 \\
\hline Central heating installation costs & 40 & 17000 & 17000 \\
\hline
\end{tabular}

Source: data of the Renewable Energy Institute

The overall operating costs of space heating and hot utility water are around $80 \%$ per year. The choice of a heating installation mostly depends on the cost of maintaining the facility. The presentation of electricity costs for a compressor heat pump in the daily G11 and mixed G12 tariff is presented in Figure 4.

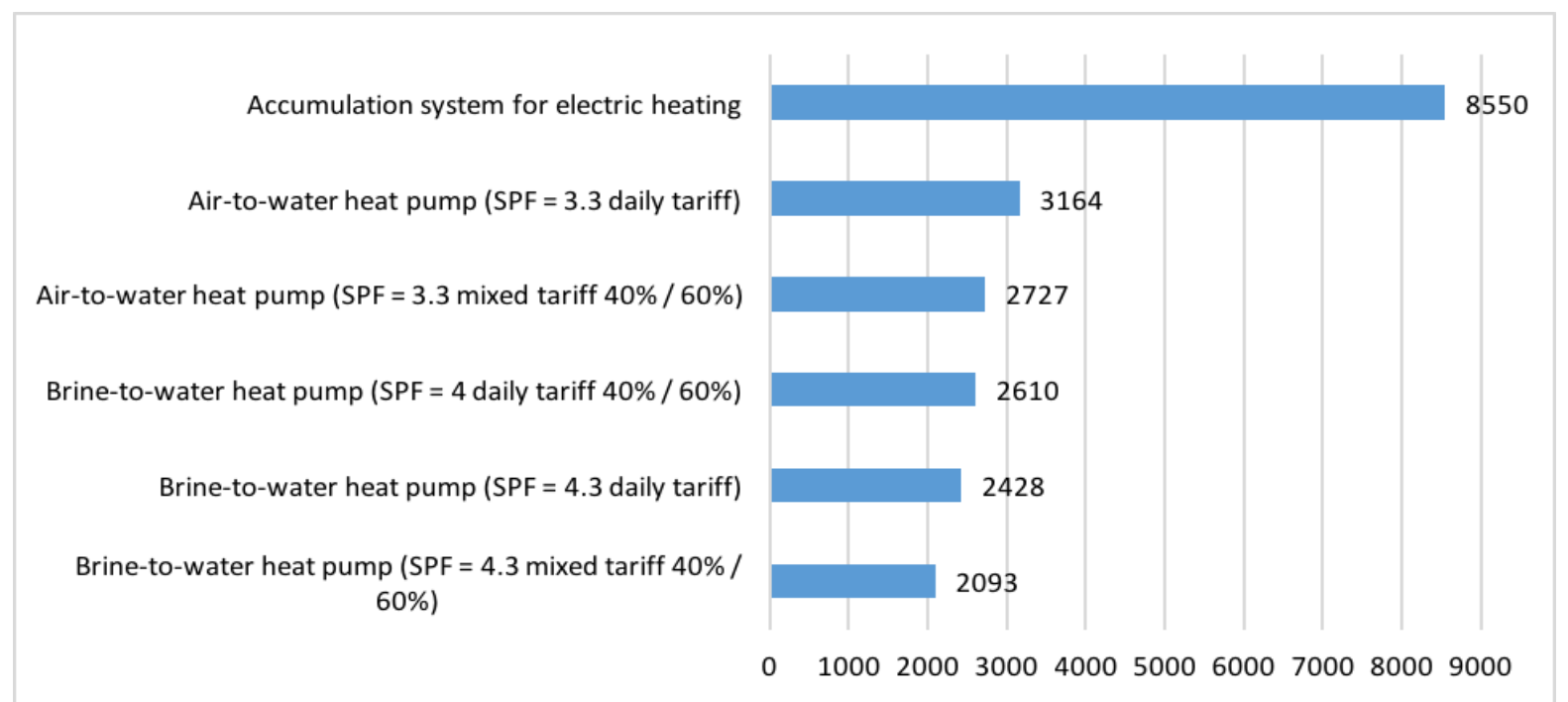

Source: data of the Renewable Energy Institute

Fig. 4. List of electricity costs for a compressor heat pump in the daily tariff G11 and mixed tariff G12 - Cost of heating hot water in a building with an area of $\mathbf{2 0 0} \mathbf{~ m}^{\mathbf{2}}$ (PLN/year)

The economic analysis of applied heat pumps in the agritourism facility considered the total costs comparing. The comparison of total equivalent annual costs (alternative assumptions) enables correct characterization of incurred costs. The guidelines of the Association of German Engineers VDI 2067 are a tool designed for economic analysis that compares selected heating technologies (Data of the Institute for Renewable Energy). The guidelines were especially appreciated in Germany. 
Energy consumption costs (ECC), capital costs (CC) and depreciation costs (DC) are the total annual financial burden that was taken into account during calculation. The capital costs concern the chosen elements work (boiler room, lower source and heat pump) in a selected operation period. The investment costs (IC) are the annual incurred fixed capital costs. The value of IC should be multiplied by a coefficient determining the equivalent annual cost or a factor characterizing the annual fees, which contain the value resulting from the use in a given period of individual investment elements and the loan interest rate. A summary of the total annual costs of using heat pumps at an agritourism farm is presented in Figure 5.

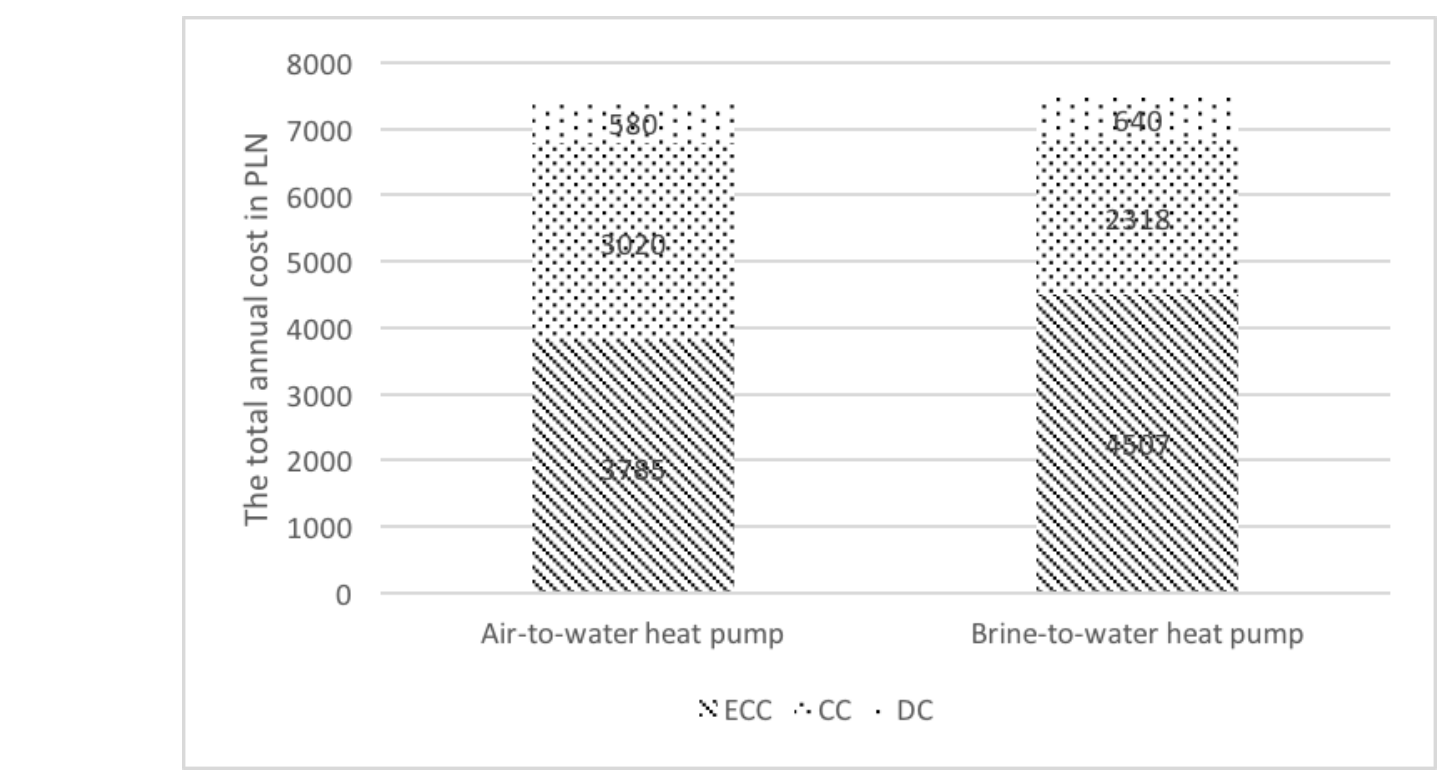

Source: data of the Renewable Energy Institute

Fig. 5. Summary of total annual costs of heat pump operation in an agritourism farm

The value of incurred costs resulting from servicing of the operating installation was presented in Figure 5. Estimation was based on the VDI 2067 guidelines. According to VDI 2067, the value of the heat pump annual maintenance is from 2 to $3 \%$ of the total investment costs. The research about FAWA heat pump exploitation that was performed in Switzerland shows that the annual service costs are significantly lower than those assumed by VDI 2067 and do not exceed the level of $1 \%$.

In the further part of the article, the energy demand $(Z)$ of agritourism farms in Poland in the years 1998-015 was estimated. Based on the above data, the formula for the energy needs in agritourism facilities was presented:

$$
\mathrm{Z}=\sum_{i=1}^{18}(\mathrm{SPH} * \mathrm{~L} * \mathrm{AF})
$$

where:

$Z$ - energy demand in agritourism farms in years, $\mathrm{J} \times \mathrm{a}$,

SHP - heat power standard, $\mathrm{kWh} / \mathrm{m}^{2}$,

$\mathrm{L}$ - average area of the farm, $\mathrm{m}^{2}$,

$\mathrm{AF}$ - number of agritourism farms in a given year.

It was estimated that every single agritourism farm for heat uses about 50.4 [TJ] energy per year. The analyses show that the energy demand of agritourism farms in the years 1998-2015 amounted to $5035816.8 \mathrm{TJ}$. This applies to the heating of agritourism facilities in Poland, which was adopted on the basis of the average area of the farm. 


\section{Conclusions}

The sustainable economic development as a part of innovativeness development leads to improvement of the living standard of the rural community. The example of the innovation is usage of heat pumps, which could be placed in rural buildings. Transformation of the energy stored in the ground into thermal energy is the purpose of described devices. The value of energy demand of agritourism farms in Poland in the years 1998-2015 amounted to 5035816.8 TJ.

It is very important to develop the innovation. The presented example of installation of heat pumps in agro-tourist facilities is a new solution that can improve the work in this type of entities. Regardless of the climate, the system can work nonstop, collecting energy from soil, surface waters, atmosphere and geothermal energy.

\section{Bibliography}

1. Bednarek-Szczepanska, M., Banski, J. (2014). Lokalizacyjne uwarunkowania oferty gospodarstw agroturystycznych $w$ Polsce (Location conditions of the offer of agritourism farms in Poland). Przeglad Geograficzny, 86 (2), pp. 243-260.

2. Dane Glownego Urzedu Statystycznego pt. Turystyka - Informacje i Opracowania Statystyczne z lat: 1998 , 1999, 2000, 2001, 2009, 2010, 2011, 2012, 2013, 2014, 2015 (Data of the Central Statistical Office Tourism - Information and Statistical Studies from 1998, 1999, 2000, 2001, 2009, 2010, 2011, 2012, 2013, 2014, 2015).

3. Dane Instytutu Energetyki Odnawialnej (Data of the Renewable Energy Institute).

4. Dane Instytutu Turystyki z lat: 2002, 2003, 2004, 2005, 2006, 2007 (Data of the Institute of Tourism from 2002, 2003, 2004, 2005, 2006, 2007).

5. Dane osrodkow doradztwa rolniczego w Polsce (Data of agricultural advisory centres in Poland).

6. Dane Polskiej Organizacji Rozwoju Technologii Pomp Ciepla (Data of the Polish Heat Pump Technology Development Organization).

7. Gaworecki, W.W. (2003). Turystyka (Tourism). PWE, Warszawa.

8. Golebiewska, B. (2015). Economic conditions of development of Polish agritourism. In. Hradec Economic Days 2015-Part IV. Vol 5(4). Hradec Králové, Gaudeamus, pp. 167-168. ISBN 978-80-7435-549-3.

9. Gospodarek, J. (2001). Prawo turystyczne (Tourist law). Wydawnictwa Prawnicze PWN, Warszawa.

10. Jedrysiak, T. (2010). Wiejska turystyka kulturowa (Rural cultural tourism). PWE, Warszawa.

11. Knecht, D. (2009). Agroturystyka w agrobiznesie (Agritourism in agribusiness). Wydawnictwo C. H. Beck, Warszawa.

12. Kozuchowska, B. (2000). Podstawowe pojecia, cechy, skladniki agroturystyki oraz formy samoorganizacji uslugodawcow . (Basic concepts, features, components of agritourism and forms of self-organization of agritourism farm owners) In. Swietlikowska U. (red.). Agroturystyka (Agritourism). Wydawnictwo FAPA, Warszawa, pp. 23-24.

13. Ollenburg, C., Buckley, R. (2007). Stated economic and social motivations for farm tourism operators. Journal of Travel Research, 45, 444-445.

14. Philip, S., Hunter, C., Blackstock, K. (2010). A typology for defining agritourism. Tourism Management, 31, pp. 754-755.

15. Prus, P., Drzazdzynska, K. (2017). Farmers' Assessment of Training Services and the Impact of Agricultural Advisory on Selected Developmental Factors Affecting Farming. Proceedings of the International Scientific Conference Economic Science for Rural Development, Latvia University of Agriculture, Jelgava, No. 44, pp. 338-344.

16. Roman, M., Niedziolka, A. (2017). Agroturystyka jako forma przedsiebiorczosci na obszarach wiejskich (Agritourism as a form of entrepreneurship in rural areas). Wydawnictwo SGGW, Warszawa.

17. Roman, M., Roman, M. (2014). Bicycle transport as an opportunity to develop urban tourism - Warsaw example. Procedia - Social and Behavioral Sciences, 151, pp. 295-297.

18. Roman, M., Roman, M., Roman, K. (2018). The forecast of economic processes of selected agricultural products in the development of bioenergy and agritourism activity in Poland. In. Double-blind peer-reviewed proceedings part II of the International Scientific Conference Hradec Economic Days. Published University of Hradec Kralove, Faculty of Informatics and Management, Hradec Kralove, vol. 8 (2), pp. 246-247.

19. Rozycki, p. (2006). Zarys wiedzy o turystyce (Outline of knowledge about tourism). Proksenia, Krakow.

20. Sikora, J. (1999). Organizacja ruchu turystycznego na wsi (Organization of tourism in the countryside). Wydawnictwo WSiP, Warszawa.

21.Sznajder, M., Przezbórska, L. (2006). Agroturystyka (Agritourism). PWE, Warszawa.

22. Wielewska, I. (2017). Eco-innovations and sustainable development of businesses in rural areas of Kujawsko-pomorskie Province of Poland. Economic Science for Rural Development. Proceedings of the International Scientific Conference, Integrated and Sustainable Regional Development Production and Cooperation in Agriculture. Jelgava: Latvia University of Agriculture. No 44, pp. 205-211. 
Proceedings of the 2018 International Conference "ECONOMIC SCIENCE FOR RURAL DEVELOPMENT" No 47

Jelgava, LLU ESAF, 911 May 2018, pp. 298-304 DOI 10.22616/ESRD.2018.035

23. Baza firm pom ciepla w Polsce (Database of heat pump companies in Poland) (2017). Retrieved: http://www.baza-firm.com.pl Access: 26.11.2017.

24. Charakterystyka budowy pompy ciepla (Characteristics of the heat pump's construction) (2017). Retrieved: http://www.gospodarzzenergia.pl/gruntowe-pompy-ciepla Access: 26.11.2017.

25. Pompy ciepla w Polsce (Heat pumps in Poland) (2017).

Retrieved: http://www.nowoczesnegrzanie.pl/pompy-ciepla.html Access: 26.11.2017. 